University of California, Hastings College of the Law UC Hastings Scholarship Repository

Faculty Scholarship

2003

\title{
The Challenge of Building an Inter-Communal Rule of Law in Helen Hunt Jackson's Ramona
}

Chimène Keitner

UC Hastings College of the Law, keitnerc@uchastings.edu

Follow this and additional works at: http://repository.uchastings.edu/faculty_scholarship

Part of the International Law Commons

\section{Recommended Citation}

Chimène Keitner, The Challenge of Building an Inter-Communal Rule of Law in Helen Hunt Jackson's Ramona, 15 Law \& Lit. 53 (2003). Available at: http://repository.uchastings.edu/faculty_scholarship/315

This Article is brought to you for free and open access by UC Hastings Scholarship Repository. It has been accepted for inclusion in Faculty Scholarship by an authorized administrator of UC Hastings Scholarship Repository. For more information, please contact marcusc@uchastings.edu. 


\section{Faculty Publications \\ UC Hastings College of the Law Library}

Author: Chimène Keitner

Source: $\quad$ Law \& Literature

Citation: 15 Law \& Lit. 53 (2003).

Title: $\quad$ The Challenge of Building an Interâ€"Communal Rule of Law in Helen Hunt Jackson's Ramona

Originally published in LAW \& LITERATURE. The article is reprinted with permission from LAW \& LITERATURE (http://www.ucpressjournals.com/journal.asp?j=lal) and the Cardozo School of Law, Yeshiva University. 


\title{
The Challenge of Building an Inter-Communal Rule of Law in Helen Hunt Jackson's Ramona
}

\author{
Chimène I. Keitner
}

\begin{abstract}
This article uses Helen Hunt Jackson's 1884 novel Ramona to ground an exploration of the problems associated with building an inter-communal rule of law. A close reading of Jackson's text reveals a rudimentary philosophy of law that comprises three central tenets: (2) a strong element of natural law thinking, which enables Jackson to construct an ideal of justice based on her conception of all individuals as members of a common humanity; (2) a critique of misunderstanding, most often rooted in ignorance, as a central stumbling-block to establishing a common legal system that unites different communities within a single territory; and (3) a deeper critique of incommensurability - the fundamental incompatibility of perspectives and values—as the greatest threat to the long-term possibility of an inter-communal rule of law, and consequently to the harmonious coexistence of different communities within a single territory.
\end{abstract}

\section{INTRODUCTION}

'Tis but a narrow line divides the zones

Where suns are warm from those where suns are cold.

'Twixt harmonies divine as chords can hold

And torturing discords, lie but semitones! '

\section{A. Overview}

The boundary between "harmonies divine as chords can hold/ And torturing discords" consists merely of "semitones," writes Helen Hunt Jackson in her

Law and Literature, Vol. 15, No. I, pages 53-86. ISSN $1535-68$ \. (C) 2003 by The Cardozo School of Law of Yeshiva University. All rights reserved. Send requests for permission to reprint to: Rights and Permissions, University of California Press, 2000 Center Street, Suite 303, Berkeley, CA 94704-1223. 
sonnet of that name. The theme of boundaries, and the misunderstandings and contestations that occur across them, permeates Jackson's late nineteenthcentury novel Ramona. Jackson wrote the novel to raise public awareness about the injustices suffered by Native Americans at the hands of white American settlers. More generally, her novel illustrates how hierarchies of race, class, and gender impede the creation of an "inter-communal rule of law." Jackson's depiction of problems associated with building an inter-communal rule of law in nineteenth-century California offers insights into similar challenges for multicultural and multinational states today.

I use the term "rule of law" to describe a system of shared norms and understandings that enables a group of people to engage in transactions with a basic degree of stability and predictability, and to have recourse to dispute settlement procedures that they regard as fair, legitimate, and binding. Such a system is "inter-communal" to the extent that it is internalized, or at least commonly understood and accepted, by people from different self-identified communities who interact with one another, most often because they inhabit the same territory. Ramona illustrates the tensions and misunderstandings that can arise when people from different communities find themselves in situations of jurisdictional overlap: in this case, Native Americans in California confronted with an influx of white American settlers.

Jackson wrote Ramona as part of an ongoing campaign to enlighten the American public about the injustices suffered by Native Americans displaced by U.S. land laws, which by and large refused to recognize pre-existing Native American titles. Although white American settlement of the frontier during the nineteenth century entailed a colonial dynamic that does not characterize all instances of inter-communality, Jackson's portrayal of this process illustrates some of the central and enduring tensions associated with creating an inter-communal rule of law. A close reading of Ramona enables us to construct a framework for examining these dilemmas with a view to understandingand ultimately tackling-the myriad frustrations and breakdowns often associated with building an inter-communal rule of law.

In Ramona, Jackson attempts to educate her readers by making the political personal. The novel is named for its heroine, a half-Native American and half-Scottish orphan who is raised by a Mexican Señora on a California estate during the territory's transfer from Mexican to U.S. rule. For Jackson, the harmonious coexistence of Mexicans and Native Americans sharing the California territory up to this point was made possible largely by economic 
interdependence and by the common faith promulgated by the old Franciscan order whose missions dot the California countryside. The decline of the missions symbolizes the decline of the old order, and signals the transition from a period of relative harmony and stability (or so Jackson portrays it) to a period of conflict and uncertainty. Ramona is flung into the midst of this conflict and uncertainty when she falls in love with a Native American man, Alessandro, and announces her intention to marry him. The Señora banishes Ramona from the estate for dishonoring the Señora's family by transgressing perceived boundaries of class and ethnicity. The saga of Ramona is the saga of Ramona and Alessandro: an exiled couple trying to find a home in a landscape that, with the arrival of white Americans, has become unfamiliar and hostile to both of them.

Although Jackson's novel was hugely popular in its day, it remains largely neglected as an important work of American literature and social commentary. Its timeless themes make it a rich source of insights into various aspects of multiculturalism and inter-communal relations. In particular, Ramona and Alessandro's exile and their subsequent misadventures highlight the kinds of tensions and misunderstandings that can impede the creation of an intercommunal rule of law.

While Americans often think of themselves as belonging to distinct cultural, religious, ethnic, and other communities within American society, they tend to take for granted that these communities now operate relatively harmoniously within a common legal and political framework. Jackson's portrait of relations among Mexicans, Native Americans, and white Americans in nineteenth-century California reminds us that the American frontier was by no means a "blank slate" at the time it was explored and settled by white Americans. While the ultimate result of the U.S. experiment was, by and large, the decimation and absorption of the Native American community into white American society, this outcome was not pre-determined. This article identifies and explores the tensions that Jackson associates with inter-communal relations in an attempt to discover what, if anything, could have fostered a more cooperative outcome.

This endeavor engages at least three non-legal fields: literature, history, and political theory. My use of a nineteenth-century novel to ground a discussion of enduring issues surrounding multiculturalism and the coexistence of different communities in a common territory stems from my conviction in the value of literature as a source of insights into timeless aspects of human char- 
acter and relationships. A close reading of Jackson's text reveals a rudimentary philosophy of law that comprises three central tenets: (I) a strong element of natural law thinking, which enables Jackson to construct an ideal of justice based on her conception of all individuals as members of a common humanity; (2) a critique of misunderstanding, most often rooted in ignorance, as a central stumbling-block to establishing a common legal system that unites different communities within a single territory; and (3) a deeper critique of incommensurability - the fundamental incompatibility of perspectives and values-as the greatest threat to the long-term possibility of an inter-communal rule of law. These problems were not unique to nineteenth-century California. Exploring Jackson's conceptions of law, justice, and community can be worthwhile in its own right, and as a means of illuminating enduring challenges in building an inter-communal rule of law, wherever communities collide.

\section{B. Analytic Framework}

As a preliminary matter, it might be useful to set out some general principles about the relationship between law and community. These principles provide the backdrop for the subsequent analysis. On a basic level, we can think of "law" as a system of shared rules, norms, and understandings accepted by a group of people as legitimate and binding with respect to their mutual interactions. As indicated above, a relatively complete and coherent system of positive laws that operates within a given population and/or territory can be called a "rule of law." We can think of a "community" as a group of individuals that identifies itself as cohesive and distinct from other groups (the subjective element), and whose network of mutual interactions is highly concentrated and characterized by shared, if often implicit, norms and understandings, particularly when contrasted with interactions between members and outsiders (the objective element). An inter-communal rule of law is a system of shared rules, norms, and understandings accepted as legitimate and binding by members of more than one community.

The main functions of law within a given community include:

Expression: indicating social values and appropriate behavior Regulation: ensuring orderly conduct of public and, at times, private affairs Facilitation: creating a stable and predictable environment for transactions Validation: fostering belief in the benefits of belonging to the community 
The "validating" function of law leads to the second set of functions, namely, those that operate at the edge of a given community:

Delineation: marking off one community from another

Separation: maintaining the distinctiveness of each community

When transgression occurs, the law takes on a more active role in the form of

Condemnation: protecting the boundaries of a given community by marginalizing, ostracizing, or otherwise punishing non-conformists.

In Ramona, the functions of expression, regulation, facilitation, and validation fail to operate across communities. Instead, the functions of delineation and separation predominate, impeding the creation of an inter-communal rule of law. In Jackson's account, white American and Native American values and ideas about appropriate behavior are not the same; the regulatory measures adopted by the U.S. government directly undermine the stability and predictability of transactions from the perspective of the Native American population; and there is no attempt to develop an inclusive ideal of American community that would embrace Native Americans without seeking to alter fundamentally their values or behavior. Not only is there misunderstanding among the communities involved, but there appears to be fundamental incommensurability: the irreconcilable divergence of perspectives and values that makes the search for a common ground elusive and ultimately futile.

Boundaries between cultures and communities are not inherently impermeable, and Jackson does not present them as such. Although one could imagine a philosophy of law that viewed the perspectives and values of distinct communities as fundamentally and irremediably incommensurable, Jackson's philosophy of law is more optimistic. The ultimate elusiveness of an intercommunal rule of law in nineteenth-century California stemmed largely from an absence of political will and incentives (economic, security-related, moral, or other) for the dominant community to work towards mutual understanding and conciliation. Given the right conditions, Jackson views mutual understanding as achievable through education, and she sees conciliation as most likely when different communities' positive legal standards converge around a natural law ideal.

I use the term "positive legal standards" to refer to the actual norms and 
practices that operate within a given community: the "law" defined above. By "natural law ideal," I mean a view of justice based on the idea of a common humanity, and the basic norms of fairness and mutual respect that flow from this. The central norm of fairness that flows from this natural law ideal is the "golden rule": treat others as you would have them treat you. In Jackson's perspective, treating members of other communities with the same respect and consideration with which one treats members of one's own community is a prerequisite for building an inter-communal rule of law.

This article explores Jackson's philosophy of law in Ramona and in her other writing. Part I.A sets out the context and purpose of Ramona. Part I.B provides an overview of the plot and characters, and the ways in which they create a framework for understanding the importance of identity, community, and belonging. Part II.A focuses on the problem of misunderstanding as a barrier to establishing an inter-communal rule of law. In Ramona, Jackson indicates that ignorance most often lies at the root of misunderstanding. The novel itself was intended to teach a generation of white Americans that Native Americans are human beings with whom they ought to sympathize and even identify. Jackson does not condemn ignorance or present it as necessarily invidious, but she does seek to counteract it through the plot and characters of Ramona. She does this positively, by teaching her white American readers about the lives of Native Americans, and also negatively, by depicting the tragic and destructive consequences of white Americans' misunderstanding and, at times, apparently willful blindness.

Part II.B looks at a stronger form of misunderstanding: the problem of incommensurability. This constitutes the most powerful challenge to the possibility of an inter-communal rule of law. Common values of mutual respect and consideration derived from a natural law ideal hold some hope for commensurability and conciliation. However, in order to realize this promise, positive law and natural law must converge. In Jackson's view, this convergence requires eliminating misunderstanding and human fallibility in the forms of selfishness, greed, irrationality, and impulsiveness. Ramona illustrates the discrepancy between U.S. positive law based on assumptions of racial superiority and entitlement to land, and a natural law ideal of human equality and due respect for the rights and claims of others. This divergence makes it impossible for Native Americans to have stable expectations, most notably in the area of land transactions. In the absence of stable expectations, a pillar of the rule of law, both order and justice are threatened. Without a basic respect for equal 
human dignity, the possibility of an inter-communal rule of law evaporates, and human relations deteriorate into a Hobbesian state of nature in which only the fittest survive.

Part III examines Jackson's letters and nonfiction writing as a guide to her philosophy of law. These sources confirm that Jackson's worldview included a heavy dose of natural law thinking, as defined above, which enabled her to discern common principles and values that ought to characterize interactions within and among communities. In Jackson's perspective, the discrepancy between ideal and actual human behavior can be attributed to greed and ignorance, and to a lack of will or incentive to transcend this. As long as human imperfections shape human behavior, an inter-communal rule of law based on mutual respect and natural justice will remain elusive. The "semitones" that divide societies will serve as effective barriers to mutual understanding, respect for a common humanity, and peace.

\section{PART I. ROMANCE AND REFORM IN RAMONA}

\section{A. Jackson's "Sugar Pill"}

Ramona, originally published in 1884 , has been through over three hundred English language editions. ${ }^{3}$ The book was Helen Hunt Jackson's second major work on the "Indian question"; the first, a report entitled $A$ Century of Dishonor, ${ }^{4}$ proved too overtly didactic to capture readers' interest and significantly influence public opinion. Jackson hoped to use the ill-fated romance of Ramona and Alessandro to stimulate public indignation and to prompt legal reform: "If I can do one hundredth part for the Indians that Mrs. Stowe did for the Negro, I will be thankful." 5 She wrote in a letter in I883: "I hope that I can write a story which will do something to influence public sentiment on the Indian question: more perhaps than my "Century of Dishonor." "6 She believed that "[p]eople will read a novel when they will not read serious books,"” and gambled that "[ $[$ ]he success of it-if it succeeds-will be that I do not even suggest any Indian history,- - till the interest is so aroused in the heroine-and hero- that people will not lay the book down." ${ }^{8}$ Her strategy was to embed her social critique in a romance so captivating that her readers would find themselves simmering with indignation before their defensive instincts and sense of self-righteousness could take hold. Interestingly, Jackson's working title for her novel while she was writing it was not Ramona, but rather In the 
Name of the Law. ${ }^{9}$ Deciding in the end that this title was too explicitly critical, she opted for a less transparent title, deciding to call her book Ramona: "I grudge giving up the other title: but I am advised strongly that it will be a mistake;--will 'show my hand,' so to speak." 10 She packaged the story as a romance, rather than proclaiming her agenda of reform.

Finding the right balance between explicit and covert social commentary proved tricky. While a twenty-first century reader is struck immediately by Jackson's stark portrayal of the poverty and insecurity of Native Americans, and of the social forces that doom the Native American hero and heroine to a tragic existence, the nineteenth-century reader was apparently less perceptive." Perhaps it was also a question of how Jackson's readers wanted to experience her text: as a vicarious journey through the dangers and adventures of life on the run as a couple in exile, or as an unflattering and incisive selfportrait of an American public blind to the cruelty and destruction being carried out on its behalf. Jackson attempted to interweave these narrative experiences so that readers who opted for the first interpretation would not remain impervious to the second.

Unfortunately, Jackson's strategy of education by stealth seems to have overshot the mark. Her so-called "sugar pill" 12 was too well-coated, and Ramona's goal of reform was largely overshadowed by its gloss of romance. Jackson began to realize this as reviews of her book were published. She wrote to one critic: "I have been much cast down by the general run of the notices of [Ramona]:- not that they did not praise the book-but nobody except you, $\&$ the N.Y. Tribune critic has seemed to care a straw for the Indian history in it."'13 Interestingly, there is a parallel to this twist in the novel itself. Jackson describes the well-concealed influence of the Señora Moreno, Ramona's guardian, on the minds of those around her, and in particular on her only son, Felipe:

To attain one's ends in this way is the consummate triumph of art. Never to appear as a factor in the situation; to be able to wield other men, as instruments, with the same direct and implicit response to will that one gets from a hand or a foot,- this is to triumph, indeed: to be as nearly controller and conqueror of Fates as fate permits. There have been men prominent in the world's affairs at one time and another, who have sought and studied such a power and have acquired it to a great degree.... But it is to be questioned whether even in these notable instances there has ever been so marvellous completeness of success as is sometimes seen in the case of a woman in whom the power is an instinct and not an attainment; a passion rather than a purpose. ${ }^{14}$ 
While Señora Moreno's talent was, in Jackson's words, "a stroke of genius," 15 it was not infallible: Felipe, though belatedly, develops a mind of his own and acts contrary to his mother's wishes. Jackson seems to have unconsciously foreshadowed her own inability to control the minds of her readers in this description of the Señora's initially overpowering, but ultimately ineffective, guile. The late nineteenth-century reading public was to Jackson as Felipe was to his mother: adoring, admiring, and indulgent, but ultimately unpersuaded by her worldview.

\section{B. Identity, Community, and Belonging}

Ramona's reform agenda is perhaps more accessible to a twenty-first century reader unencumbered by (as many) colonialist defense mechanisms. On a broader level, it is a story about what happens when historically and culturally distinct communities come into contact with each other, and the friction that arises at their points of intersection. This section looks more closely at Ramona's plot and characters as sources of insight into Jackson's views on inter-communal relations.

The action of the novel unfolds in Southern California, against the backdrop of the decline of the old Mexican estates and Franciscan missions that dominated the landscape up until the late nineteenth century. These communities are portrayed as living in relative harmony with the indigenous Native American population; Jackson, who was not herself religious, ${ }^{16}$ wrote in Ramona of the "deep-seated attachment on the part of the Indians and the older Mexican families in the country to the Francis[c]an Order." ${ }^{17}$ Her nostalgic portrayal of the relationship among the Mexicans, the Native Americans, and the Franciscan monks ${ }^{18}$ likely did not represent an endorsement of the old order so much as a strategy of romanticizing the past in order to more effectively condemn the present. Jackson's description of the loss of land and deterioration of community experienced by the Mexicans and the Franciscans with the arrival of white Americans paints a more generalized picture of the disrespect for tradition and custom with which white American settlers treated all prior inhabitants of their newly conquered territory.

Ramona, the heroine of the novel, is a mixture of multiple communities: born to a Scottish father and a Native American mother, raised by a prosperous Mexican family, and schooled at a convent. ${ }^{19}$ The Señora Moreno raises Ramona because of a promise to the Señora's dying sister, who was herself 
Ramona's adoptive mother. Ramona does not know her family history until the Señora chooses to reveal it to her during one of the novel's dramatic climaxes. ${ }^{20}$ All she knows is that the she is not the Señora's own daughter, and that the Señora somehow resents her presence in the Moreno family:

A nature less gentle than Ramona's would have been embittered, or at least hardened, by this consciousness. But Ramona's was not. She never put it in words to herself. She accepted it, as those born deformed seem sometimes to accept the pain and isolation caused by their deformity. ...21

Jackson's use of deformity as an analogy is telling: Ramona perceives that she is somehow different and does not belong, but she remains stoic in the face of differential treatment at the hands of Señora Moreno. The Señora provides for all of Ramona's material needs (fulfilling the "positive law" requirements of her promise to her sister ${ }^{22}$ ), but she does not love the child and cannot pretend to do so. Jackson writes that the Señora "did not wish any dealings with such alien and mongrel blood. 'If the child were pure Indian, I would like it better,' she said. 'I like not these crosses. It is the worst, and not the best of each, that remains." "23 For the Señora, Ramona's white blood is not redemptive. ${ }^{24}$ All of the Señora's own children, except for her son Felipe, died in infancy, ${ }^{25}$ and Felipe has a delicate constitution and is often ill. While Jackson includes these details to further explain the Señora's resentment towards Ramona, they could also be read to indicate the greater health and resilience of mixed communities, as opposed to the "in-breeding" and insularity of Felipe's aristocratic progenitors.

Alessandro, though a full-blooded Native American, is also distinctive in ways that make him more acceptable to white society (and thus more sympathetic to Jackson's readers). However, these same characteristics threaten to alienate him from his own community: "He was a distant, cold boy, his own people of the Temecula village said. It had come, they believed, of learning to read, which was always bad. Chief Pablo had not done his son any good by trying to make him like white men." ${ }^{26}$ Alessandro's talent for playing the violin and his gentle nature make the Señora well-disposed towards him, especially when he succeeds in nursing Felipe back to health. Tellingly, the Señora thinks of Alessandro: "How the boy makes one forget he is an Indian!'”27 Nevertheless, when Ramona announces her intention to marry Alessandro, his Native American blood proves an insurmountable barrier for the Señora, despite Ramona's own mixed parentage. ${ }^{28}$ Although Felipe initially supports 
the marriage, he is persuaded by his mother's reasoning. The Señora coaches him:

"Of course it would not be right for us to let Ramona do anything which we would not let her do if she were really of our own blood. ... My sister intended to rear her as her own daughter. She had given her her own name. When my sister died, she transferred to me all her right and responsibility in and for the child. You do not suppose that if your aunt had lived, she would have ever given her consent to her adopted daughter's marrying an Indian, do you?"29

Felipe feels constrained to accede to this line of argument: "He saw the meshes closing around him. He felt that there was a flaw somewhere in his mother's reasoning, but he could not point it out; in fact, he could hardly make it distinct to himself." ${ }^{30}$ His mother's legalistic reasoning based on the positive obligations attached to the "transfer" of her sister's "right and responsibility in and for the child" defies refutation, even though Felipe feels that it is somehow twisted and does not reflect his own conception of right and wrong, based on natural justice and the imperative of treating all individuals with equal respect and consideration. Felipe also knows that Ramona will not accept his mother's law as binding: "Only one thing he saw clearly, and that was, that after all had been said and done, Ramona would still marry Alessandro." 31

Felipe's intuition proves correct, and Ramona resolves to flee the Moreno estate and live with Alessandro in his village, Temecula. During the days leading up to her flight, she persists in her refusal to obey the Señora's prohibition. The Señora responds by insisting that "Ramona should be made to feel, every moment of every day, that she was in disgrace; that she was with them, but not of them; that she had chosen an alien's position, and must abide by it." 32 In the Señora's view, Ramona has forfeited her membership in the Moreno family, a community to which Ramona had belonged legally, if not genetically or emotionally. In addition, the Señora judges that Ramona has forfeited her inheritance from the Señora's sister, which the Señora had been instructed to give Ramona unless she married "unworthily." 33

Ramona readily forfeits these material goods in order to marry Alessandro. ${ }^{34}$ They travel to San Diego, where they are married by Father Gaspara. Alessandro calls Ramona Majel, the Indian word for "wood-dove," and she chooses to register herself under this name in the marriage record book, along with her biological father's last name, Phail. With this transformative act, Ramona literally re-writes her identity, as Ramona Ortegna becomes Majella 
Phail—or Majella Fayeel, as Father Gaspara understands it and records it in the register. ${ }^{35}$ The couple cannot return to Alessandro's village, Temecula, since it has been taken over by American settlers. They travel instead to San Pasquale, where Alessandro finds Ysidro, another Temecula Indian. Ysidro, at first disquieted by this interracial marriage, is ultimately reassured:

A look of swift intelligence from Alessandro reassured him. "Indian on the mother's side!" said Alessandro, "and she belongs in heart to our people. . . . The name Majel I have given her, for she is like the wood-dove; and she is glad to lay her old name down forever, to bear this new name in our tongue."36

In this fashion, Ramona is accepted into the Native American community, although, as she soon discovers, it is a community fighting for its very survival.

To a certain extent, Jackson portrays community belonging as a voluntary act of self-identification on the part of the would-be member, ratified by the community's acceptance of that identification. However, while Ramona's decision to link her fate to that of Alessandro and his community is voluntary, the other Native Americans do not have an exit option. Their identity and membership are not as precarious as Ramona's, but they are also not as flexible. Ramona ultimately exercises her "exit option" at the end of the novel when she moves with Felipe to Mexico. ${ }^{37}$ Jackson assumed her readers would realize that most Native Americans did not have this luxury. Her faith in the American public's ability —or willingness_- to recognize and accept responsibility for the plight of Native Americans turned out to be less well-founded than she had anticipated. ${ }^{38}$ The plot's portrayal of community membership as to a certain degree voluntary risked undermining its condemnation of the consignment of Native Americans to unjust treatment based solely on their community identity.

\section{PART II. OBSTACLES TO AN INTER-COMMUNAL RULE OF LAW}

\section{A. The Problem of Misunderstanding}

The failure of white Americans to treat Native Americans as full human beings worthy of equal respect and consideration stemmed largely from the 
pervasiveness of stereotypes. Jackson believed that many negative stereotypes of Native Americans were a product of ignorance. She herself admitted: "It was one of my childish terrors that Indians would come in the night, \& kill us!" 39 Jackson set out to remedy these misconceptions in Ramona, although she did so in a somewhat condescending manner. A representative passage from Ramona illustrates the point:

[The Temecula Indians are poor], replied Felipe, "compared with us; but one reason is, they share everything with each other. Old Pablo feeds and supports half his village, they say. So long as he has everything, he will never see one of his Indians hungry."

"How generous!" warmly exclaimed Ramona; "I think they are better than we are, Felipe!"

"I think so, too," said Felipe. "That's what I have always said. The Indians are the most generous people in the world. Of course they have learned it partly from us; but they were very much so when the Fathers first came here. You ask Father Salvierderra some day. He has read all Father Junipero's and Father Crespi's diaries, and he says it is wonderful how the wild savages gave food to every one who came." 40

In teaching her readers about the generosity of Native Americans, Jackson is careful not to go too far: Felipe offers not only on his own observations as evidence to support his opinion, but also the written accounts of the Franciscans. He still refers to the Native Americans as "wild savages," even though he has just agreed with Ramona's statement that "they are better than we are." Despite his "enlightened" attitude towards Native Americans, Felipe's vocabulary is still laden with stereotypes.

During their exile from the Moreno household, Ramona and Alessandro encounter the Hyers, a white American family: Joss, Jeff, and Aunt Ri. Through Aunt Ri, Jackson gives voice to the surprise of a white woman at being liberated from her preconceptions about Native Americans. Although Aunt Ri makes many comments on the subject, one passage is worth quoting at length. The Hyers have just met Ramona and Alessandro, who stumbled upon their shelter in a snowstorm. Jos, the son, speaks enough Spanish to act as an interpreter; at times, the reader wishes he would also interpret Jackson's rendition of his mother's dialect! Aunt Ri explains to her husband Jeff:

"I jest tell you thet I've got a lesson 'n the subjeck uv Injuns. I've always hed a reel mean feelin' about 'em; I didn't want ter come nigh 'em, nor ter hev 'em 
come nigh me. This woman, here, she's ez sweet a creetur's ever I see; 'n' ez bound up 'n thet baby's yer could ask enny woman to be; 'n' 's fur thet man, can't yer see, Jeff, he jest worships the ground she walks on? Thet's a fact, Jeff. I donno's ever I see a white man think so much uv a woman; come, naow, Jeff, d' yer think yer ever did yerself?"

Aunt Ri was excited. The experience was, to her, almost incredible. Her ideas of Indians had been drawn from newspapers, and from a book or two of narratives of massacres, and from an occasional sight of vagabond bands or families they had encountered in their journey across the plains. Here she found herself sitting side by side in friendly intercourse with an Indian man and Indian woman, whose appearance and behavior were attractive; towards whom she felt herself singularly drawn. ${ }^{41}$

For Aunt $\mathrm{Ri}$, who is empathetic by nature, ignorance is the sole cause of misconceptions and misunderstandings about Native Americans. When she hears of the expulsion of all the Native Americans from the villages of Temecula and San Pasquale, she insists: "I don't bleeve the Guvvermunt knows anything about it! ... Why, they take folks up, 'n' penetentiarize 'em fur life, back 'n Tennessee, fur things thet ain't so bad's thet! Somebody ought ter be sent ter tell 'em 't Washington what's goin' on hyar." ${ }^{42}$ Aunt Ri immediately perceives the double standard being applied to those who displace Native Americans: "Why, they take folks up, 'n' penetentiarize 'em fur life, back 'n Tennessee, fur things thet ain't so bad's thet!" Because her own preconceptions were caused solely by ignorance, she assumes that any injustice perpetrated by her compatriots must arise from the same deficiency. She cannot believe that a well-informed government would permit such a scandal, much less facilitate it.

In the end, Aunt Ri modifies her position slightly, adding the caveat that information must be acquired first-hand in order to serve its purpose of correcting misconceptions:

“Oh, I'm done talkin' agin Injuns, naow, don't yeow furgit it! But I know, fur all thet, 't won't make any difference; 'pears like there cudn't nobody b'leeve ennythin' 'n this world 'thout seein' 't theirselves. I wuz thet way tew; I allow I hain't got no call ter talk; but I jest wish the hull world could see what I've seen! Thet's all!"43

In this passage, Jackson lends credence to the idea that "you have to see it to believe it." Nevertheless, Jackson hoped that Ramona would let the "hull world" see what she had seen on her travels in California, so that others would 
be inspired to do something about it. Disseminating information disguised as leisure reading was one way to help the Native American cause.

Jackson realizes that misunderstanding is neither always innocuous, nor easily remedied. Her plot becomes heavy as Ramona's first child dies from a lack of basic medical treatment. At about this time, Alessandro begins succumbing to the pressure of exile and gradually loses his mind. During one of his fits of disorientation and amnesia, he is murdered by a vengeful white settler. Jackson's account of the murder - a fictionalized version of an actual event ${ }^{44}$ —reveals the destructive potential of misunderstanding in the starkest possible terms. It also demonstrates that information alone is insufficient to produce relationships based on mutual respect and understanding: human empathy is also required.

As Alessandro comes to realize that his search for a safe refuge from white settlers is futile, he begins literally to lose his mind. In one of his psychotic fits, he takes a white man's horse, leaving his own in its place. Everyone in the region, including the horse's owner, knows of Alessandro's illness, and knows that he always returns property as soon as he comes to his senses. Nevertheless, the owner, Farrar, a white man, goes to Alessandro's home and shoots him point-blank in the chest, plus twice in the head while he is lying on the ground, dying. ${ }^{45}$

Judge Wells, who finds himself in charge of the case, faces a dilemma. He takes Farrar into custody, as is his positive-law "duty," ${ }^{46}$ and he delays the preliminary hearing for a week to give Ramona time to recover from the delirium caused by the event, so that she can appear as a witness. But Ramona does not recover in time, and Wells, with "a strange mixture of regret and relief," 47 is forced to dismiss the charges against Farrar. He reflects to himself that "to betray sympathy with Indians was more than any man's political head was worth. The word 'justice' had lost its meaning, if indeed it ever had any, so far as they were concerned." 48 Judge Wells acknowledges, but is unwilling or unable to contest, the divergence between a discriminatory positive law and an egalitarian ideal of natural justice. He knows very well that Farrar could not have mistaken Alessandro for an actual horse thief:

... no one knew better than Judge Wells that Alessandro in his sense was as incapable of stealing a horse as any white man in the valley. Farrar knew it; everybody knew it. Everybody knew, also, about his strange fits of wandering mind; and that when these half-crazed fits came to him, he was wholly irresponsible. Farrar knew this. ${ }^{49}$ 
The Judge also knows that Farrar never would have shot a white man in the same situation. ${ }^{50} \mathrm{He}$ consoles himself with the thought that Farrar would have been acquitted regardless, "for there would never have been found a San Diego County jury that would convict a white man of murder for killing an Indian, if there were no witnesses to the occurrence except the Indian's wife." 51 The problem here was not a lack of information: as Jackson repeats twice in Wells's ruminations, "Farrar knew ..." Yet without empathy-without a desire and a willingness to understand the situation — misunderstandings occur, and double standards persist. Farrar's willful blindness to Alessandro's condition made him treat Alessandro like a horse thief; a jury's lack of information and empathy would have led them to acquit him regardless of the underlying facts. A society incapable of deterring and punishing unjustified aggression against all individuals might have law, but it does not have justice.

In sum, Jackson's novel suggests that a just and legitimate rule of law cannot encompass different communities in the absence of mutual understanding. This problem of misunderstanding based on ignorance is exacerbated by the difficulty of cross-cultural communication. Jackson's two examples of misunderstanding demonstrate that information alone is insufficient to remedy the problem. The first example has a positive outcome: the transformation of the attitude of Aunt Ri and her family towards Native Americans. The second is negative: the murder of Alessandro and the failure of the U.S. legal system to punish the killer. Taken together, these episodes indicate that information is a necessary but not sufficient condition for understanding. In addition to information, understanding requires human empathy: a capacity to contemplate the position of the other, and a willingness to entertain perspectives other than one's own.

\section{B. The Problem of Incommensurability}

The problems of willful blindness and double standards that lead to Farrar's murder of Alessandro and to the dismissal of the charges against him also characterize white Americans' treatment of the inhabitants of California with respect to land. Jackson lays the foundation for her moral argument against U.S. land policy without mentioning Native Americans. Instead, she begins by describing the encroachment of the white settlers on the Mexican and Franciscan communities: 
The boundaries [of General Moreno's land] were not very strictly defined; there was no occasion, in those happy days, to reckon land by inches. It might be asked, perhaps, just how General Moreno owned all this land, and the question might not be easy to answer. It was not and could not be answered to the satisfaction of the United States Land Commission, which, after the surrender of California undertook to sift and adjust Mexican land titles.... Tract after tract, [the Señora's] lands had been taken away from her; it looked for a time as if nothing would be left. ... No wonder she believed the Americans thieves, and spoke of them always as hounds. ${ }^{52}$

The idea of "incommensurability," on a literal level, refers to the impossibility of comparison based on a common standard. In Isaiah Berlin's political thought, the incommensurability of values is the hallmark of pluralism: values can be ranked and balanced within cultures, but not across them. ${ }^{53}$ In the above passage, Jackson indicates that the question of land ownership not only "was not" answered to the satisfaction of the U.S. authorities: it "could not" be answered to their satisfaction. While the disregard for Mexican land titles was motivated largely by greed and expediency, the incommensurability of Mexican and American conceptions of ownership and methods of recording title enabled white Americans to seize land from individual owners without breaking the law as they understood it.

Although white American settlers felt that they were living under the rule of law, with rules that guided their behavior and provided avenues of redress, the Mexicans and Native Americans living in California did not share this perception. To the contrary, they lost the stability of expectations that had characterized their prior existence, and that ought to exist in a law-governed society:

Moreover, [the Señora] declared that she should never feel secure of a foot of even this [land]. Any day, she said, the United States Government might send out a new Land Commission to examine the decrees of the first, and revoke such as they saw fit. Once a thief, always a thief. Nobody need feel himself safe under American rule..$^{54}$

To the Señora, the Americans are "thieves": a word that denotes those who take property in violation of the law. Her conception of law is clearly different from that of white Americans. In particular, her feeling that the American idea of law is subject to change at any moment prevents her from enjoying stable expectations and the security that comes with knowing that one's entitlements 
are clearly defined and protected by authoritative institutions. If we evaluate the existence of the rule of law based on the experiences of all those living within a given territory, and not just those who have consented (either directly or indirectly) to be bound by the law, then the rule of law cannot be said to have existed vis à vis the Mexicans and Native Americans during this period of California history.

Although Jackson eases her readers into a discussion of the injustice of U.S. land policy by focusing first on the situation of Mexican land owners, her true focus is the plight of Native Americans. In contrast to A Century of Dishonor, which examines the Native American land question analytically, ${ }^{55}$ Ramona provides a narrative account designed to influence readers' minds through their hearts and their consciences. The first blow to Alessandro comes when he discovers that a Mexican landowner's promise to his father, Pablo, that the Temecula valley would remain undisturbed, might not be legally valid under the American system:

This man's promise to Pablo, that he and his people should always live in the valley undisturbed, was all the title Pablo had to the village lands. In the days when the promise was given, it was all that was necessary. The lines marking off the Indians' lands were surveyed, and put on the map of the estate. No Mexican proprietor ever broke faith with an Indian family or village thus placed on his lands.

But Pablo had heard rumors, which greatly disquieted him, that such pledges and surveyed lines as these were coming to be held as of no value, not binding on purchasers of grants. He was intelligent enough to see that if this were so, he and his people were ruined..$^{56}$

This excerpt suggests that the passage of time is one factor in the erosion of Pablo's land claim: "In the days when the promise was given, it was all that was necessary." However, had the Mexicans retained control of this region, Jackson suggests that the promises to the Native Americans would have been honored: "No Mexican proprietor ever broke faith with an Indian family or village thus placed on his lands." The displacement of the Mexicans by white Americans results in the erasure of existing titles and the imposition of a new legal system hostile to the Native Americans' claims.

It is only a matter of time before the accuracy of Pablo's premonition is confirmed, and white American settlers take over the Temecula village, ejecting all the Native Americans who reside there: 
"I don't know who they are," Alessandro replied, his voice full of anger and scorn. "They're Americans,-eight or ten of them. They all got together and brought a suit, they call it, up in San Francisco; and it was decided in the court that they owned all our land. That was all Mr. Rothsaker could tell about it. It was the law, he said, and nobody could go against the law." ${ }^{\text {7 }}$

The American settlers also take the villagers' cattle and horses to pay for the suit, as stipulated by the court's judgment. ${ }^{58}$ Jackson emphasizes throughout that all of the injustices she is describing are explicitly authorized by U.S. positive law, as the original title of her novel, In the Name of the Law, indicated. Ramona stands as an indictment not only of the individuals who profited from an unjust system, but also of the positive legal rules that facilitated and conferred legitimacy on actions that would otherwise have constituted theft.

Alessandro understands that "the law" is against him-a law that is founded on neither the custom nor the consent of his community, but that applies to him regardless:

"Yes; [the Temecula valley] is theirs," said Alessandro, doggedly. "That is the law. They've got all the papers to show it. That is what my father always said,if the Señor Valdez had only given him a paper! But they never did in those days. Nobody had papers. The American law is different." 59

The boundary between the Mexican and American communities is expressed in terms of both the passage of time ("they never did in those days") and the incompatibility of legal systems ("The American law is different."). Furthermore, even the existence of "a paper" is no guarantee that the Americans will respect it:

Father Gaspara had gone with Ysidro to a lawyer in San Diego, and had shown to this lawyer Ysidro's paper, - the old one from the Mexican Governor of California, establishing the pueblo of San Pasquale, and saying how many leagues of land the Indians were to have; but the lawyer had only laughed at Father Gaspara for believing that such a paper as that was good for anything. He said that was all very well when the country belonged to Mexico, but it was no good now; that the Americans owned it now; and everything was done by the American law now, not by the Mexican law anymore..$^{60}$

The Americans seem to abandon their requirement of "a paper" when it is convenient, a further indication of the absence of respect for the customs and practices of non-white communities. 
Like the Señora, Alessandro views the Americans as thieves who are violating both the existing laws of the region (consisting of customs and promises that the Mexicans and Native Americans considered binding), and the natural law precepts of justice and respect for human dignity. For him, the conduct of the American settlers under the aegis of U.S. law reflects on all of American society:

"If there are Americans who are good, who will not cheat and kill, why do they not send after these robbers and punish them? And how is it that they make laws which cheat? It was the American law which took Temecula away from us, and gave it to those men! The law was on the side of the thieves."61

Within a law-governed community, thieves are those who break the law. Alessandro's statement that " $[\mathrm{t}]$ he law was on the side of the thieves" relies on a definition of "thief" that appeals to his own conception of legality, based on customs, promises, and an ideal of natural justice. If U.S. positive law conformed to natural law or respected existing customs and promises, there would not be an incommensurability problem. The failure of an inter-communal rule of law is not unavoidable, but it would require information, empathy, and a revision of positive law rules to make U.S. law just, legitimate, and binding in the eyes of the Mexican and Native American communities.

Because the law is "on the side of the thieves," U.S. legal institutions will not recognize or protect Alessandro's land rights. ${ }^{62}$ The only recourse is a return to the state of nature, where Native Americans can confront the settlers on a level playing field, unencumbered by a biased legal system. Knowing that he will be driven from San Pasquale as he was from Temecula, Alessandro decides to sell his house and farmland to a white American settler before it is seized by force:

"I suppose I can have them without paying you for them, if I choose," said the man, insolently.

"No, Señor," replied Alessandro.

"What's to hinder, then, I'd like to know!" in a brutal sneer. "You haven't got any rights here, whatever, according to law."

"I shall hinder, Señor," replied Alessandro. "I shall burn down the sheds and corrals, tear down the house; and before a blade of the wheat is reaped, I will burn that." Still in the same calm tone.

"What'll you take?" said the man, sullenly.

"Two hundred dollars," replied Alessandro.

"Well, leave your plough and wagon, and I'll give it to you," said the man; 
"and a big fool I am, too. Well laughed at, I'll be, do you know it, for buying out an Indian!"63

As the settler points out, Alessandro hasn't got "any rights here, whatever, according to law." However, the "law" the settler is referring to is the positive law of the United States, which is only binding on those who either ( $\mathrm{I}$ ) accept it or (2) can be forced to obey it. Alessandro knows that he is powerless to keep his land, but he can destroy its value. He asserts the power of human agency in the face of the impersonal law that the settler wields as a weapon: "I shall hinder, Señor." Positive law, standing alone, is not sufficient to shape individuals' behavior: it must be backed by a belief in its legitimacy (so that people will comply voluntarily), and by effective enforcement mechanisms (to sanction non-compliance). Alessandro pinpoints the flaw in the settler's belief in the all-encompassing nature of positive law, and uses this gap to exact some payment for land that, if he could, he would refuse to sell.

In the end, Ramona and Alessandro find that they cannot keep defying the law: they must escape its reach entirely. Just as they fled the Señora's estate when she would not consent to their marriage, they seek refuge in the mountains once they realize that no Native American village will remain safe: "Let us go to the mountain to-night!" [Ramona] gasped. "Take me where I need never see a white face again!" 64 Even this desperate plan does not succeed, as the need for Alessandro to earn an income takes him into the villages where, as described above, he ends up riding off with a white man's horse and being gunned down by its owner.

Escaping civilization altogether is impossible: in situations of "invasion," the only choices are to become a part of the invading community, ${ }^{65}$ or to find a place where one's own community can exist unmolested. As a sympathetic Los Angeles settler wrote in a letter to Jackson, "[the Indians] tell me that all they wish is for the Government to mark them out a place where they can live in peace, and be quiet." 66

Felipe reaches the same conclusion. After Alessandro has been murdered and the Señora has died, Felipe finally succeeds in locating Ramona, whom he has been trying to find ever since she fled. Felipe and Ramona are married, and they raise Ramona and Alessandro's second daughter as their own. They no longer feel at home in California. Jackson writes of Felipe:

He found himself more and more alone in the country. Even the Spanish tongue was less and less spoken. He was beginning to yearn for Mexico,-for 
Mexico, which he had never seen, yet yearned for like an exile. There he might yet live among men of his own race and degree, and of congenial beliefs and occupations. ${ }^{67}$

Felipe and Ramona move to Mexico, where they are both welcomed into the Mexican community. Their search for security dovetails with their search for home: only at "home" do positive laws reflect the values, customs, and practices of the community, and the community's understanding of the requirements of justice. Even though Felipe is not physically displaced from his property by the American settlers, he feels displaced by the invasion of their legal system, which he, like the Native Americans, perceives as unjust and unpredictable. He was born and raised in California, but it is only in Mexico that he finds the familiarity and sense of belonging "among men of his own race and degree, and of congenial beliefs and occupations." Ramona and her child are also welcomed into the Mexican community, an indication of Jackson's view that racial and ethnic identity is not a prerequisite to belonging in the presence of understanding and empathy.

As Ronald Dworkin suggests, "political obligation-including an obligation to obey the law-is a form of associative obligation." 68 The associative ties of community support the legitimacy of law, both procedurally and substantively. While communal identities and structures can be multiple and overlapping, the overarching legal structure of a political entity cannot be sustained in the long run without the inclusive support of the population it purports to govern. If the excluded community is not politically mobilized, the dominant community might win a short-term victory in the form of continued domination or assimilation, but such arrangements are unlikely to be sustainable in the longer term. Feelings of exclusion and marginalization can lead to civil disobedience, rebellion, and even violence. History has shown that political demands based on past injustices and fueled by a marginalized community's persistent sense of subjugation and disfranchisement can challenge and destabilize even the most well-entrenched political and legal systems.

\section{PART III. JACKSON'S RUDIMENTARY PHILOSOPHY OF LAW}

This section looks more closely at Jackson's philosophy of law as expressed in her letters and in A Century of Dishonor. The two components of this under- 
standing of law that emerge from Jackson's nonfiction writing are, as indicated above: (I) positive law standards, which may or may not reflect the ideal of natural justice; and (2) the natural law ideal reflected in the golden rule (for this reason, the terms "natural law ideal" and "natural justice" are essentially interchangeable when discussing Jackson's philosophy of law). I will briefly discuss each of these components in turn.

\section{A. Jackson's View of Positive Law}

At first glance, Jackson's view of U.S. positive law seems uniformly critical. By "U.S. positive law," I mean the set of codified norms and institutional practices promulgated by the U.S. government in its dealings with Native Americans. A central purpose of codifying law is to promote fairness by providing a bulwark against arbitrary modification of a society's governing rules. However, as Jackson illustrates, positive law can in fact become a barrier to justice, as it did for Native Americans.

Jackson refers repeatedly to the disjunction between U.S. positive law and the ideal of natural justice, since U.S. positive law refused to recognize customary titles and titles held by Native Americans that were not legally sound under the (largely self-serving) U.S. rules. However, Jackson refrains from advocating rebellion or civil disobedience in opposition to positive laws, however unjust these may appear. For example, she lamented upon hearing that the U.S. government had issued an order to move all the Native Americans out of the village of Saboba: "It is a terrible outrage on humanity-but I suppose the [Interior] Department is powerless to interfere,- - the land having been patented." ${ }^{69}$ She elaborated in another letter:

A whole village-150 or 200 -all just about to be "ejected" from a tract they have cultivated for nearly 100 years-It is a horrible outrage-Yet I myself, cannot see what the Int[erior] Dep[ar]t[ment] can do to help it.-The Indians had no title-never have had, in any sense in which our Land Laws recognize. ${ }^{70}$

Even though Jackson disagreed strongly with the refusal of "our Land Laws" to recognize Native Americans' title to land, she acknowledged their ultimate authority to govern land transactions. Her description of the unfair laws as "our Land Laws" indicates her identification with and acceptance of U.S. positive laws as the necessary structure holding together white American society and preserving social order. Her letters indicate a struggle to reconcile 
her sense of indignation and injustice with the recognition that U.S. positive law was a complete system with its own internal logic, ${ }^{71}$ and that denying this logic would mean eroding the foundation of the entire system.

Over the course of the nineteenth century, land to which Native Americans did not have a recognized title was "patented" by the U.S. government and sold to private settlers. Once land had been patented, it could be sold on the market. For a market to be successful, it must be stable and secure; as Jackson recognized, "[ $\mathrm{t}]$ here is no going back on a patent." 72 Even though she doubted the good faith of many private purchasers, ${ }^{73}$ she acknowledged their right to rely on the government's representations that land in the market was available and free from legal encumbrances: "Why did the Govt. put these lands in market, if it were not right for us to file on them'? has been said more than once, by resentful settlers. And the question was a logical one."74 The scheme of positive law created by the U.S. government did not always conform to principles of justice; however, in cases of divergence, Jackson deferred to positive law in view of the reliance interests of private parties and the need for finality in settling disputes as a basic element of social order.

The best illustration of Jackson's acceptance of the primacy of positive law, even when it contradicted her ideal of natural justice, can be found in one of her letters. The letter is particularly illuminating in its attempt to reconcile the apparent injustice of the U.S. government's frontier policy with American ideals of democracy and self-government. Jackson wrote the letter to a teacher whose Native American students were imploring her to explain why they were being forced off their land. She counseled:

If I were in your place, this is the way I should try to put it to [the Native American children].-

Ist The President is not like a King. He himself has to obey the law, just as much as any other man.-

The law is made by the Great Council, (Congress) To the Great Council go men from every state:- \& they all together, make the law.-When it is made, everybody must obey it.-

No white man can own any piece of land unless he has got the papers to prove he owns it.-not even the President can own any piece of land unless he has the papers to prove it.

The reason the Saboba people are in such trouble now, is because their fathers did not have any papers from the Mexican Government to prove the land was theirs.- 
The Great Council have left a good deal of land free, to all people to go and live on, when they will select it, and then pay for their papers:- And of this free land, "Government Land", the President can give places to the Indians to live on:- and if the Saboba Indians have to be moved, he will give them, the very best there is left. ${ }^{75}$

Although this passage sounds to modern ears like unabashed apologism, it represents Jackson's best effort to reconcile existing positive law with American values and with her conception of natural justice. The ideals of non-arbitrary rule ("The President ... has to obey the law"), collective deliberation and decision-making (" $\&$ they all together, make the law"), equal applicability of the law to all members of the community ("When it is made, everybody must obey it"), and fairness and even generosity as a default rule in the absence of positive legal prescriptions ("he will give them, the very best there is left"), seem to map an essentially unexceptionable rule-of-law landscape.

The trick, of course, and the central problem, lie in the definition of community membership: the "they" that make the law does not encompass all those who must abide by it. The positive law created by the U.S. government was deemed to apply to lands that the Native Americans occupied when California belonged to Mexico; when this land became a U.S. territory with the Treaty of Guadalupe Hidalgo in 1848 , the geographical reach of U.S. law became wider than its population base. ${ }^{76}$ U.S. laws were deemed to apply to communities that had had no part in making them, and whose members often did not understand their implications. While no laws are actually made by each and every individual they govern, the exclusion of an identifiable community from democratic decision-making, particularly in an area that vitally affects that community, seriously impairs the claim of the resulting laws to be legitimate and binding. To the extent that it did not view an affected community's exclusion from decision-making as a fatal impediment to the legitimacy of positive laws, Jackson's philosophy of law was, though progressive for her time, ultimately incomplete.

\section{B. Jackson's Natural Law Ideal}

Interestingly, in discussing U.S. policy towards the Native Americans, Jackson initially conceptualized the relationship between the white American and Native American communities as subject to international law, and to the 
international legal principle of justice ${ }^{77}$ — what we might today call the doctrine of reciprocity. She proposed that the core international legal principle of keeping promises should control the U.S. government's dealings with Native Americans. ${ }^{78} \mathrm{Her}$ reliance on this international legal principle suggests that, at least initially, her rudimentary ideal of an inter-communal rule of law had more in common with international law than it did with "domestic" law. It is generally accepted that international legal principles rely on a "thinner" conception of justice than domestic legal principles, since different countries are not presumed to share substantive values. Adherence to common procedural rules facilitates interaction among countries, even in the absence of consensus on substantive values. In the traditional (and now largely outdated) conception, the realm of international law ended where a country's borders began. This is where an international law model becomes insufficient as a framework for inter-communal relations: when different communities share a common territory, the necessity of frequent interaction and overlapping jurisdictions makes "thinner" conceptions inadequate to fulfill coherently the functions of expression, regulation, facilitation, and validation. This is likely one reason why Jackson ultimately turned to her conception of natural justice as a source of substantive principles that could structure relationships among different communities inhabiting a single territory.

On a concrete level, although the United States proclaimed itself to be "one nation," the incorporation of Native American communities into the U.S. territory through treaty and conquest challenged the plausibility of this conception and the ability of U.S. law to claim to represent the substantive values of all individuals subject to it. As suggested above, this disjunction between theory and demography also threatened to undermine assumptions about the legitimacy and binding nature of the results of democratic decision-making in an ostensibly participatory government, as critics of the long-standing disenfranchisement of women and African-Americans have emphasized.

As indicated above, Jackson's natural law ideal is rooted in her strong sense of justice, best articulated as a commitment to treating all human beings with equal consideration and respect. Her commitment to this ideal of justice stands in tension with her acknowledgment of the authoritative force of positive law, even when it diverged from this ideal. ${ }^{79}$ In reading her letters, her reports, and her novel, one discerns that, for Jackson, justice entails giving each person his or her due. Individuals are entitled to be treated with equal respect for their persons and their property, regardless of their community membership. Jackson 
makes clear her view that imposing the U.S. government's positive law on the Native American community violates the principle of equal respect for persons and property. However, Jackson stops short of advocating disregard for the commands of U.S. positive law in the area of land claims, even where these are manifestly unjust when viewed from a natural law perspective. Instead, she argues passionately for making these positive law rules conform to the demands of justice, that is, for making U.S. land policy towards the Native Americans observe the golden rule.

While Jackson does not herself use the language of "positive law" and "natural justice," this dichotomy structures much of her basic thinking on the treatment of Native Americans. Jackson's reports and letters are replete with references to the demands of "justice," which have not been met by U.S. policy towards Native Americans. In $A$ Century of Dishonor, she wrote of the treatment of Native Americans: "It is a shame which the American nation ought not to lie under, for the American people, as a people, are not at heart unjust." ${ }^{80}$ Jackson remained convinced that the injustice of U.S. land policy resulted from general ignorance and misunderstanding, not from the fundamentally "unjust" nature of "the American people."

Jackson expressed her objections to the gap between U.S. government policy and the ideal of natural justice through a variety of channels. In a letter published in the New York Tribune in the winter of 1879-1880, she criticized a government decision to stop issuing rations to the Utes tribe in Colorado in response to an uprising by certain members of that tribe. Her appeal to natural law arguments in the ensuing debate reveals the limits of her faith in and willingness to respect positive laws. Jackson wrote:

And now the Secretary of the Interior has stopped the issue of rations to 1000 of these helpless creatures; rations, be it understood, which are ... the Utes' rightful dues, on account of lands by them sold; dues which the Government promised to pay "annually forever." Will the American people justify this? There is such a thing as the conscience of a nation-as a nation's sense of justice. Can it not be roused to speak now? 81

Jackson invokes the government's explicit promise to supply rations to the Indians, and she relies for support on the principle that promises must be kept. ${ }^{82}$ However, as this citation indicates, she also draws on an overarching conception of natural justice, irrespective of the positive laws that apply in a given situation. 
Having read Jackson's appeal to ideas of obligation and justice, William $\mathbf{N}$. Byers, the former editor of the Denver newspaper Rocky Mountain News, wrote in a lengthy reply: "In withholding supplies from the White River Utes the Secretary of the Interior is simply obeying the law." ${ }^{83}$ Byers holds his interpretation of positive law up to Jackson's conception of natural law. Jackson's reply again relies on her natural law ideal, in contrast to her deference to positive law in the area of land claims. She accuses Byers of endorsing "punishing the innocent for the crimes of the guilty," ${ }^{84}$ and she advocates a more discerning principle of justice that refrains from ascribing collective guilt. In urging a requirement of individual criminal responsibility, Jackson appeals to the Tribune's readers' innate sense of what is right and wrong, fair and unfair. The contention that the Secretary was "simply obeying the law" in withholding the rations, whether or not it is an accurate interpretation of positive law, fails the test of natural justice.

Another tenet of natural law that Jackson invokes in her original letter involves an obligation of the strong to protect the weak: the "helpless creatures" who depend on government rations for their survival. For Jackson, the U.S. government has a clear obligation to prevent the destruction of Native American communities. ${ }^{85}$ In a letter to Henry Teller, the Secretary of the Interior, she deploys pragmatic arguments in support of government intervention, but she places the greatest emphasis on the ideal of justice:

It seems clear that the government ought to defend these Indians' rights. . . . And for that matter so far as expense is concerned, it will be far cheaper for the government to do this, than to move the village, and establish it elsewhere. But it is not a question of cost. It is a question of right and obligation..$^{86}$

In protecting Native Americans' rights, it is important to respect their dignity, and to realize that they will resist paternalistic solutions. Jackson wrote to Hiram Price, the Commissioner for Indian Affairs:

I am entirely sure that to propose to those self supporting farmers, to submit themselves to the usual reservation laws and restrictions would be futile. It would be also, insulting. There is no more right or reason in an Indian Agent with the usual Indian Agent's authority, being set over them, than there would be in attempting to bring the white farmers of Anaheim or Riverside under such authoritative control..$^{87}$ 
The idea that policy-makers ought to assume that Native Americans would have the same qualities of pride, honor, self-respect, and dignity as "the white farmers of Anaheim or Riverside" was apparently far from self-evident. One of Jackson's main goals in Ramona was to introduce her readers to the notion that Native Americans could be, in many ways, just like them. ${ }^{88}$

As noted above, Jackson's working title for her novel while she was writing it was not Ramona, but rather In the Name of the Law-a title that indicated much more directly the true purpose of her narrative. This title has been interpreted as "in keeping with [Jackson's] explicit desire to give fictional form to a legal argument for compensation already set forth in A Century of Dishonor." In fact, the title can be read as going beyond an argument for compensation, and implicating the idea of the rule of law itself. When injustices can be committed "in the name of the law," any rule of law that does exist is based on positive law only. ${ }^{90}$ Such a system lacks the moral foundations of natural law principles that enable people to feel that their written laws and institutional practices reflect what is fundamentally right and fair. In Jackson's view, as long as this disjunction persists no inter-communal rule of law can be created, since members of the subordinated community will never accept its legitimacy. Moreover, the moral fabric of the dominant society is bound to suffer as its self-image as a just community breaks down in the face of manifest injustice perpetrated in its name and through its legal and governmental institutions.

\section{CONCLUSIONS}

Laws within a given community serve the functions of delineation and separation, in this case most explicitly by applying differentially to members and to non-members. The informal norms that support the legal framework condemn those who seek to deviate from the accepted model: the Señora banishes Ramona for her transgressive behavior, and several of Jackson's characters, including Judge Wells and the man who bought land from Alessandro, remark on the social and political cost of appearing sympathetic to Native Americans. What is required, at a minimum, is a more inclusive conception of community and a basic commitment to treating all human beings with equal respect and consideration. Otherwise, there will remain insufficient foundations upon which to build a just, non-assimilationist, and genuinely inter-communal rule of law in a multicultural or multinational society. 
In addition to revealing these basic elements of Jackson's philosophy of law, Ramona also conveys a strong moral message. Readers of Ramona cannot help but sense, whether or not they internalize or accept this message, that although white Americans were the "survivors" in their conquest of Native American land and communities, the price of this victory may have been the moral fabric of the society they built on its ruins.

Jackson's novel does not contain a theory of multiculturalism. Although Jackson seems to suggest that an inter-communal rule of law can exist if positive laws reflect natural law precepts, she does not address the question of how to deal with instances of "true incommensurability," when the problem is not simply a lack of information or empathy, but a real conflict between deeply held and mutually exclusive beliefs and practices. It seems that, in such situations, the only logical options are assimilation or exile, neither of which is necessarily possible or desirable. Jackson does not go so far as to label an intercommunal rule of law impossible, but her narrative and analysis arguably point in that direction. The destabilizing potential of residual illegitimacy in a legal system created through conquest, coupled with the precariousness of that system's moral claim to be binding on members of historically excluded groups, presents an ongoing tension in political and legal systems whose purported inclusiveness is belied by the historical record.

The "semitones" in Jackson's sonnet, with which this Article began, may be "subtle" boundaries, but they still mark sharp divisions between warm zones and cold zones, divine harmonies and torturing discords. Some of these divisions cannot be bridged. There might be a middle ground between hot and cold, but not between harmonious chords and musical dissonance. Although the imperative that a rule of law be internally coherent is generally intra-communal, situations may arise in which a legal system is called upon to regulate the behavior of members of more than one community who find themselves living in the same territory or under the same political institutions. In such situations, Jackson's insights in Ramona may take on more than academic interest.

The question of the rule of law in a multicultural society is of great contemporary importance; in identifying this problem, Ramona was a novel ahead of its time. Without sensitivity to the problems involved in creating an intercommunal rule of law, attempts to do so risk leading to injustice and insecurity. The expectations and constraints placed on non-members of the dominant community may be different depending on the historical circumstances 
that brought different communities under a common jurisdiction (for example, voluntary immigration vs. involuntary annexation). A comprehensive theory of the rule of law in multicultural societies would have to address such differences. Until such a theory is developed through the writings of scholars and novelists and the experiments of politicians and diplomats, we will continue to confront the basic question: How do we create an overarching legal framework that will be accepted as legitimate and binding by people with fundamentally different backgrounds and beliefs?

1. Helen Hunt Jackson, Sonnets and Lyrics (Boston: Roberts Brothers, 1886), p. 122.

2. See infra note 79 for more on the term "rule of law."

3. Michael Dorris, Introduction, in Helen Hunt Jackson, Ramona (New York: Penguin, 1988), at v.

4. Helen Hunt Jackson, A Century of Dishonor: A Sketch of the United States Government's Dealings with Some of the Indian Tribes (Williamstown, MA: Corner House, 1973) [hereinafter Century of Dishonor]. In 1883 , President Chester Arthur appointed Jackson a Commissioner of Indian Affairs, so she could officially report on the condition of California's Mission Indians. The result of her investigations, which she conducted along with Abbot Kinney, was entitled Report on the Condition and Needs of the Mission Indians of California; it was issued by the Government Printing Office in I883. Dorris, supra note 3 , at $\mathbf{x}$.

9. Helen Hunt Jackson to William Hayes Ward, Jan. I, 1884, in The Indian Reform Letters of Helen Hunt Jackson, 1879-1885, Valerie Sherer Mathes, ed. (Norman: University of Oklahoma Press, 1998), p. 307 [hereinafter Indian Reform Letters].

6. Helen Hunt Jackson to Ephraim W. Morse, Nov. 3, 1883, in id., at 296; see also Helen Hunt Jackson to Thomas Bailey Aldrich, Nov. 24, 1883, in id., at 300; Helen Hunt Jackson to Unknown, Jan. 22, 188 , in id., at $34 \mathrm{I}$.

7. Helen Hunt Jackson to Antonio F. \& Mariana Coronel, Nov. 8, 1883, in id., at 298.

8. Helen Hunt Jackson to An Intimate Friend, Feb. 5,1884 , in id., at 314.

9. Helen Hunt Jackson to Thomas Bailey Aldrich, May 4,1883 , in id., at 258 ("Such heart sickening fraud, violence, cruelty as we have unearthed here-I did not believe could exist in civilized communitiesand 'In the Name of the Law.' "); see also Helen Hunt Jackson to Thomas Bailey Aldrich, Nov. 24, 1883, in id., at 300 ("The title is so good, it seems to me, it must have been used, I hope not. I want it. No other will suit my purpose."); Helen Hunt Jackson to Thomas Bailey Aldrich, Dec. 4, 1883, in id., at 306. ("If you find out that 'In the Name of the Law' has been used, my heart will be broken.")

Io. Helen Hunt Jackson to Thomas Bailey Aldrich, March 10, 1884, in id., at 318 . This letter provides an answer to the question Valerie Sherer Mathes, who edited the collection, had implicitly posed in an earlier work on Jackson, in which she had stated that Jackson changed the title of the book from In the Name of the Law to Ramona "for unknown reasons." Valerie Sherer Mathes, Helen Hunt Jackson and Her Indian Reform Legacy (Austin: University of Texas Press, 1990), p. 81.

II. "Jackson hoped that Ramona would be the Uncle Tom's Cabin of the Indian reform movement. It failed to accomplish her original intent. Instead of being perceived as an indictment of the assault of AngloCalifornia society upon the California Indians, it was seen as a romantic love story that bec[a]me a stock symbol of southern California chambers of commerce and tourist bureaus." Mathes, supra note 10, at xiv; 82-83. See also Carl Gutiérrez-Jones, Rethinking the Borderlands: Between Chicano Culture and Legal Discourse (Berkeley: University of California Press, 1995), p. 57. ("Yet as the reception of the 
novel has demonstrated, readers may grant the romantic elements such importance that all other considerations become virtually invisible.")

12. Helen Hunt Jackson to Unknown, Jan. 22, 1885, in Indian Reform Letters, supra note 5, at 341. ("In my Century of Dishonor I tried to attack people's consciences directly, and they would not listen. Now I have sugared my pill, and it remains to be seen if it will go down.")

13. Helen Hunt Jackson to Charles Dudley Warner, Dec. 25, 1884, in id., at 338; see Helen Hunt Jackson to Unknown, Jan. 13, 1885, in id., at 34I ("I am positively sick of hearing that 'the flight of Ramona \& Alessandro is an idyl' - \& no word for the Temecula ejectment."). In her despair, Jackson determined that her next project would be a children's story on the Indian theme, which she hoped would better serve its purpose, since " $[\mathrm{t}]$ he children have more heart than grown up people." Id. Jackson died of cancer on August 12, 188, , before this project could be realized. Id., at 352 n.I.

14. Ramona, supra note 3 , at 11 .

I5. Id.

16. See Mathes, supra note 10, at 89 . (Jackson objected to an article on her personal life which mentioned "her picknicking thirteen Sundays in a row. Jackson retorted that the world did not need to know she was a "champion Sabbath breaker.'")

17. Ramona, supra note 3 , at 18 .

18. For historical background, see Robert H. Jackson, Indians, Franciscans, and Spanish Colonization: The Impact of the Mission System on California Indians (Albuquerque: University of New Mexico Press, 1995).

19. See Ramona, supra note 3 , at 24-28, 33 .

20. Id., at $132-33$.

2r. Id., at 33. Jackson's failure to address specifically the plight of "mestizos," given her heroine's mixed race, has been criticized as fuelling a "systematic historical amnesia" about "the rising mestizo class that Jackson must have walked among." Gutiérrez-Jones, supra note il, at 69 .

22. See Ramona, supra note 3 , at $90-91$.

23. Id., at 30 .

24. See id., at 31. ("No wonder, perhaps, that she never loved the child. It was a sad legacy, indissolubly linked with memories which had in them nothing but bitterness, shame, and sorrow from first to last.")

25. Id., at 18 .

26. Id., at 51 .

27. Id., at IoI; see also Gutiérrez-Jones, supra note II, at 60 . ("Led by the desire to present the Mission Indians as potentially full-fledged citizens, ... Jackson creates exceptional Native American characters who are described as standing apart from their race as much as representing it.")

28. See Ramona, supra note 3 at $132-33$.

29. Id., at $145-46$.

3o. Id., at 146 .

31. Id., at 146.

32. Id., at 155 .

33. Id., at 125,357 .

34. Id., at 134 .

35. Id., at 236 .

36. Id., at 244 .

37. To Felipe's initial surprise, Ramona is delighted at the prospect of moving to Mexico so that her daughter, whose father is Alessandro, can grow up there: “And as she spoke, Felipe understood by a lightning intuition, and wondered that he had not foreknown it, that she would spare her daughter the burden she had gladly, heroically borne herself, in the bond of race." Id., at 359. The double meaning of the word "bond" expresses the idea that race can be both a link of solidarity and a constraint or burden.

38. See Mathes, supra note 10, at 84 . ("According to historian Allan Nevins, Jackson erred by having the 
faithful cousin Felipe rescue the heroine after the death of her husband and her tragic flight from the village. Ramona, instead, should have been forced to live in misery and squalor. This happy ending ruined Jackson's effect of portraying a wronged people.")

39. Helen Hunt Jackson to Charles Dudley Warner, Oct. 2, 1884 , in Indian Reform Letters, supra note s, at 330; see also Ramona, supra note 3, at 228. (" "The stupid Indians fight and kill, and then what can we do? The white men think we are all the same.' ")

40. Ramona, supra note 3 , at 78 .

41. Id., at 286 .

42. Id., at 291 .

43. Id., at 348; see also id., at 259. ("If the people who make these laws could only see this village, they would never turn us out, never! They can't know what is being done. I am sure they can't know.'”)

44. Helen Hunt Jackson to Mary Elizabeth (Sheriff) Fowler, Dec. $1,188_{3}$, in Indian Reform Letters, supra note 5 , at 305,306 n.2.

45. Ramona, supra note 3 , at 316 .

46. Id., at 319 .

47. Id., at 321 .

48. Id.

49. Id., at 322 .

5o. Id.

51. Ramona, supra note 3, at 321; see also id., at 318. ("Never yet within their experience had a white man been punished for shooting an Indian.")

52. Id., at 12.

53. For a succinct presentation of this idea in the context of Isaiah Berlin's political thought, see Henry Hardy, Isaiah Berlin's Key Idea, available at http: //www.wolfson.ox.ac.uk/berlin/vl/writings_on_ ib/hhonib/isaiah_berlin's_key_idea.html.

54. Id. at 13 .

55. Jackson begins this study with a clear and eloquent discussion of the nature of Native American rights in land. Century of Dishonor, supra note 4, at 9-17.

56. Ramona, supra note 3, at 52; see also 66-67.

57. Id., at 177 .

58. Id., at $178-79$.

59. Id., at 179 .

6o. Id., at 257 ; see id., at 237 (" 'But do not trust to [the paper], son. Buy yourself a piece of land as the white man buys his. Trust to nothing."); see also id., at 203. ("I have got the feeling now that nothing will be of any use against the Americans. I don't believe they will mind the paper.")

61. Id., at 239; see also id., at 258-59. ("What more is it, then, which you wish to know, my brother, about the American laws?' he said. 'Is it not enough that you know they have made a law which will take the land from Indians; from us who have owned it longer than any one can remember; land that our ancestors are buried in,--will take that land and give it to themselves, and say it is theirs?" ")

62. In her correspondence with the U.S. Secretary of the Interior, Jackson quotes a letter from "a Boston lady" on the issue of lands belonging to the Ponca tribe: " " $[\mathrm{I}] \mathrm{t}$ is worth ten times $\$ 10,000$ to prove that if the Government seizes land given to the Indians forever by solemn compact, the latter can by the courts recover it.' " Helen Hunt Jackson to Secretary [of the Interior] Schurz, Jan. 9, 1880, in Century of Dishonor, supra note 4 , at 360 .

63. Ramona, supra note 3 , at 265.

64. Id., at 307; see also id., at 308 ("There is no help for us, Majella, only to hide; that is all we can do!").

65. Although Jackson has been criticized as assimilationist, see supra note 32, her biographer suggests that it was instead her successors who adopted assimilationist arguments: "Interested in preserving the land base for future generations of California Mission Indians, [Jackson] opened the door to reformers who were much more divisive and destructive of Indian culture." Mathes, supra note ro, at xvi; 4, 6, 8-9. 
66. Extracts from Don Antonio Coronel's letter to Helen Hunt Jackson, copied by Jackson in a letter to Henry Teller, Nov. 14, 1884 , in Indian Reform Letters, supra note 5 , at 335 .

67. Ramona, supra note 3 , at 359 .

68. Ronald Dworkin, Law's Empire (Cambridge, MA: Belknap, 1986), p. 206.

69. Helen Hunt Jackson to Hiram Price, March 10, 1883 , in Indian Reform Letters, supra note 5 , at 247.

70. Helen Hunt Jackson to Joseph Benson Gilder, March I2, I883, in id., at 249.

71. See Helen Hunt Jackson to Hiram Price, March 10, 1883 , in id., at 247. ("The men who have patented this San Jacinto Valley know that this Indian village of Saboba has been there for nearly a hundred years:its lands not only cultivated, but fenced and irrigated.-They do not recognize this as 'occupation.'”)

72. Helen Hunt Jackson to Mary Elizabeth (Sheriff) Fowler, March 12, 1883, in id., at 249.

73. See, e.g., Jackson's discussion of the San Diego Co. settlers in Helen Hunt Jackson to Hiram Price, Nov. 25,1883 , in $i d$. at 303 .

74. Helen Hunt Jackson to Hiram Price, May $5,188_{3}$, in id. at 264.

75. Helen Hunt Jackson to Mary Elizabeth (Sheriff) Fowler, March 19,1883 , in id. at 253.

76. Jackson writes in Ramona: "Mexico saved much by her treaty, spite of having to acknowledge herself beaten; but California lost all. Words cannot tell the sting of such a transfer. It is a marvel that a Mexican remained in the country; probably none did, except those who were absolutely forced to it." Ramona, supra note 3 , at 13 .

77. See Century of Dishonor, supra note 4 , at 20-22.

78. See $i d$., at 22.

79. As I have defined it, a rule of law must be internally consistent, but does not necessarily need to conform to external (or "natural") standards of justice in order to be viewed as a rule of law. One might differentiate between $a$ rule of law, which consists primarily of positive legal rules shared within a given community (or among several communities in a given territory), and the Rule of Law, which connotes a system in which positive legal rules conform to principles of natural justice. For an elaboration of the characteristics often associated with the term "rule of law," see generally Joseph Raz, The Authority of Law: Essays on Law and Morality (Oxford: Clarendon, 1979), pp. 214-218.

80. Century of Dishonor, supra note 4 , at 7.

81. Helen Hunt Jackson to the Editor of the New York Tribune, Jan. 31, 1880, in id. at 346.

82. This is what H.L.A. Hart would refer to as a "secondary rule"; see H.L.A. Hart, The Concept of Law (Oxford: Clarendon, rev. ed. 1994).

83. William N. Byers to the Editor of the New York Tribune, Feb. 6, I880, in Century of Dishonor, supra note 4 , at 350 .

84. Helen Hunt Jackson to the Editor of the New York Tribune, Feb. 22, 1880, in id. at 356.

85. See, e.g., Helen Hunt Jackson to Mary Elizabeth (Sheriff) Fowler, May 4, 1882, in Indian Reform Letters, supra note 5, at 228. ("I have written a long letter to the Secretary of the Interior, Mr. Teller, whom I know personally, I have told him about the position of these Indians here in S. Cal. and the certainty that they will be driven off every one of their homesteads in a few years, if the Govt. does not protect them.")

86. Helen Hunt Jackson to Henry Teller, May 16,1883 , in id., at 269

87. Helen Hunt Jackson to Hiram Price, Oct. 3I, 1882, in id., at 24I.

88. For a critique of the assimilationist logic implicit in this strategy, see, for example, Gutiérrez-Jones, supra note II, at 54 (referring to Ramona as a "legally inflected domestic romance that effectively sentences Mexicanos to a silent, withdrawn existence — to a 'solitary confinement' that may well appease Anglo audiences who want to identify with, and thereby share, the experience of victimization in a manner that does not expose their complicity in the initial or ongoing disenfranchisement."). For a general critique of assimilationism with respect to the Latino community, see George A. Martinez, "Latinos, Assimilation and the Law: A Philosophical Perspective," 20 Chicano-Latino L. Rev I (1999).

89. Gutiérrez-Jones, supra note II, at 58.

90. See supra note 79 . 